\title{
Marie-Pierre Rey, L'effroyable tragédie. Une nouvelle histoire de la campagne de Russie
}

\section{Michel Arrous}

\section{(2) OpenEdition}

1 Journals

\section{Édition électronique}

URL : https://journals.openedition.org/studifrancesi/3135

DOI : 10.4000/studifrancesi.3135

ISSN : 2421-5856

Éditeur

Rosenberg \& Sellier

\section{Édition imprimée}

Date de publication : 1 juillet 2013

Pagination : 469

ISSN : 0039-2944

\section{Référence électronique}

Michel Arrous, "Marie-Pierre Rey, L'effroyable tragédie. Une nouvelle histoire de la campagne de Russie », Studi Francesi [En ligne], 170 (LVII | II) | 2013, mis en ligne le 30 novembre 2015, consulté le 02 février 2023. URL : http://journals.openedition.org/studifrancesi/3135; DOI : https://doi.org/10.4000/ studifrancesi.3135

Ce document a été généré automatiquement le 2 février 2023.

\section{(c)}

Creative Commons - Attribution - Pas d'Utilisation Commerciale - Pas de Modification 4.0 International - CC BY-NC-ND 4.0

https://creativecommons.org/licenses/by-nc-nd/4.0/ 


\title{
Marie-Pierre Rey, L'effroyable tragédie. Une nouvelle histoire de la campagne de Russie
}

\author{
Michel Arrous
}

\section{RÉFÉRENCE}

MARIE-PIERRE REY, L'effroyable tragédie. Une nouvelle histoire de la campagne de Russie, Paris, Flammarion, 2012, pp. 390.

1 En privilégiant un regard comparatiste, Marie-Pierre Rey a donné de la campagne de 1812 une histoire globale et, ce qui est nouveau, attiré l'attention sur la dimension humaine de la guerre totale. L'historiographie française a souvent salué le génie militaire de Napoléon, le courage de ses soldats, et même soutenu que la Grande Armée avait été militairement invaincue, sinon par le "général hiver», tout en édulcorant les exactions commises et en relativisant les succès des Russes qu'expliquait l'alcool distribué par Koutouzov... La terrible réalité est précisément évoquée par des témoignages (parfois tardifs) et, surtout, par le recours à des sources croisées. Parmi ces témoignages, celui de Stendhal, cité à trois reprises, dont on mesure mieux la difficulté de la mission à Smolensk grâce à un clair exposé des conditions dans lesquelles elle fut menée. On lira avec profit les chapitres sur l'atroce bataille de Borodino (la Moskowa) à laquelle Stendhal assista, sur Moscou occupée et son gigantesque autodafé, sur le pillage auquel participèrent aussi des Russes. Quelques anecdotes font écho au journal de Stendhal. Parmi les sources utilisées, on retrouve celles que Stendhal avait privilégiées: Labaume, qui évoqua à mi-voix des cas d'anthropophagie, Robert Wilson et Ségur. On regrettera que les légendes du cahier iconographique soient incomplètes: la prise de Smolensk en feu est de Langlois qui est aussi l'auteur du portrait du «brave des braves», les toiles sur la retraite et le passage de la Bérézina sont de Pryanishnikov (1874) et de Suchodolski (1866). On aurait pu 
ajouter la Retraite de Moscou d'Ary Scheffer qui égalait aux yeux de Stendhal les meilleures pages de Ségur. 